\title{
Self-assembled peptidic nanostructures
}

\author{
Sila Toksöz, Mustafa O. Guler*
}

UNAM-Institute of Materials Science and Nanotechnology, Bilkent University, 06800 Ankara, Turkey

Received 6 July 2009; received in revised form 19 August 2009; accepted 22 September 2009

Available online 13 October 2009

\author{
KEYWORDS \\ Self-assembly; \\ Peptides; \\ Nanomaterials; \\ Amphiphiles; \\ Supramolecular \\ chemistry
}

\begin{abstract}
Summary Understanding the mechanisms of molecular self-assembly processes in natural materials is an important step to developing new functional materials with useful properties. Recently, various self-assembled materials have gained attention because of their interesting properties in nanoscale. Nanostructures composed of peptides are especially of interest in materials development because of their many advantageous properties such as biodegradability, biocompatibility and customizable bioactivity. Self-assembled peptidic nanostructures have been studied by many research groups and found use as three-dimensional cell scaffolds for bone regeneration, dental implants, neural tissue engineering, biosensors for detection of viruses and other pathogens, antibacterial agents and in drug, protein and gene delivery. (c) 2009 Elsevier Ltd. All rights reserved.
\end{abstract}

\section{Introduction}

Life was made possible by the assembly of monomers such as nucleic acids, fatty acids, amino acids, which came together to form larger molecules, namely proteins, carbohydrates and lipids. By understanding the mechanisms of self-assembly processes in living organisms, scientists realized that self-assembling structures could provide vast opportunities for the design of new materials for both biological and non-biological applications, in fields such as regenerative medicine [1-4], electronics [5-8] and optics [9]. Molecular self-assembly is a technique in materials design, involving non-covalent interactions such as hydrogen bonding, hydrophobic, electrostatic, metal-ligand, $\pi-\pi$ and van der Waals interactions. These interactions are

\footnotetext{
* Corresponding author. Tel.: +90 312290 3552; fax: +903122664365 .

E-mail address: moguler@unam.bilkent.edu.tr (M.O. Guler).
}

highly dynamic and often delicate due to their relatively weak nature, varying from less than $5 \mathrm{~kJ} \mathrm{~mol}^{-1}$ for van der Waals interactions to up to $120 \mathrm{~kJ} \mathrm{~mol}^{-1}$ for hydrogen bonding, compared to covalent bonds which can have energies up to $400 \mathrm{~kJ} \mathrm{~mol}^{-1}$ [10]. However, a sufficient number of these weak interactions can yield a stable assembly. Various self-assembled supramolecular nanostructures have been prepared using these non-covalent interactions [11-14] and many new self-assembling materials can be designed to organize into ordered complex structures by understanding the mechanisms of these assembly processes.

\section{Supramolecular nanostructure formation inspired by nature}

Understanding interactions in assembly mechanisms of biological molecules has become a crucial factor in designing nanoscale materials. Among various examples of selfassembling molecules found in the nature, proteins are of particular interest in terms of supramolecular organization. 
Proteins are formed by tertiary structures of peptide secondary structures. The information needed for secondary and tertiary structures are encoded in the amino acids, which are the smallest protein building blocks that carry the information needed to create higher levels of organization. Amino acids can contain chirality, electrostatic dipoles, ionizable groups, hydrogen-bond donors and acceptors, hydrophobic domains and metal binding ligands [15]. A considerable number of the interactions in proteins consist of either $\alpha$-helix or $\beta$-sheet secondary structural components of peptides [16].

One of the most abundant protein-folding motifs is the 'coiled-coil' [17], in which $\alpha$-helices with a seven-residue repeat sequence are coiled intertwiningly. One year after the discovery of the structure of $\alpha$-helix by Pauling et al. [18], Crick proposed that the structure of $\alpha$-keratin is based on coiled coils [19]. Most coiled-coils adopt a left-handed structure although it is possible to find some right-handed coiled coils naturally or artificially [20].

Leucine zippers, named by Landschulz et al. [21], are a special type of coiled-coil structural motif involved in the dimerization of a number of transcription factors, the best characterized and most versatile coiled-coil structure being the leucine zipper of the yeast transcriptional factor GCN4 [22]. The interactions stabilizing the leucine zippers are hydrophobic interactions between nonpolar side chains and the intra- and interhelical electrostatic interactions between charged amino acids [23].

Amyloid plaques contain a different type of structure formed by very stable peptide and protein complexes $[24,25]$. Amyloid fibers implicated in Alzheimer's disease are composed of well-ordered $\beta$-sheet structures and are sensitive to the amino acid sequence forming the peptide. The $\beta$-sheet structures found in the amyloid proteins provide a strong and stable aggregation. Inspired from the mechanical stability of the amyloid systems, new functional nanoscale materials can be designed based on the $\beta$-sheet secondary structures of the peptides [8].

Interest in self-assembly of peptides and proteins has been motivated not only by a concern to understand the mechanisms of pathological aggregation but also to understand the functions and mechanisms of higher order assembly of proteins such as collagen. Natural collagen has been found useful in enhancing cell adhesion [26], tissue regeneration [27-29], and drug delivery [30,31]; therefore, scaffolds and biomaterials mimicking the natural collagen and enhancing its biological functions have been generated [32-36].

Tobacco mosaic virus (TMV) is another form of supramolecular nanostructure, assembled from a single strand of mRNA and many copies of identical coat proteins helically organized into a rod-like shape [37]. The RNA is inserted between the protein turns with three nucleotide residues per protein subunit. Each protein subunit is situated at a radial distance of $4 \mathrm{~nm}$ from the central axis, where the outer diameter of the formed nanotube is $18 \mathrm{~nm}$. The protein arrangement forces the RNA backbone into a moderately extended single-strand configuration which forms the central axis of the virus particle within a cylindrical hole. TMV capsule has multiple applications as a scaffold to fabricate materials with nanoscale order [38-40] due to its welldefined structure, stability and easy mass production (Fig. 1)

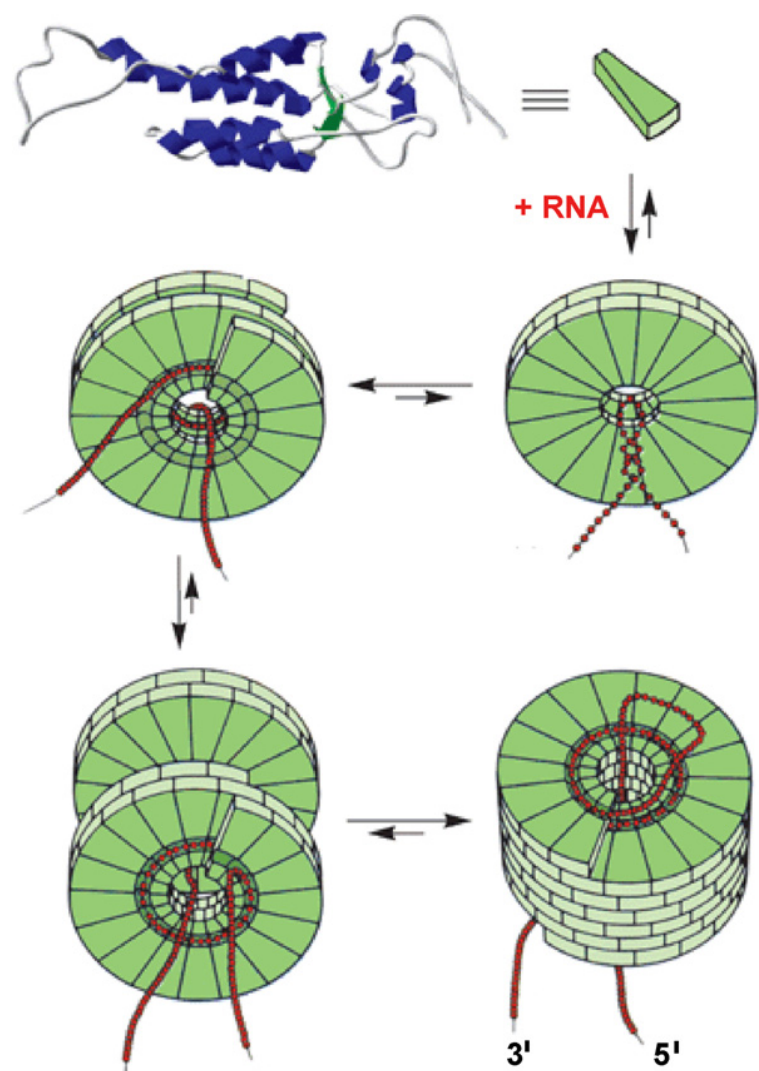

Figure 1 The assembly of the tobacco mosaic virus. Reproduced with permission from Ref. [41].

$[41,42]$. Although use of the TMV as templates for selective deposition has been achieved, the covalent attachment of small molecules to the capsid has been more difficult to achieve. That the future applications will depend critically on functionalization, Schlick et al. developed new synthetic methods which enable functionalizing capsids without disrupting their assembly [43]. As a result of these studies, the usefulness of TMV for construction of nanoscale materials has been increased dramatically. The utilization of the modified capsids as carriers for drug and gene delivery is under investigation.

\section{Peptide-based supramolecular nanostructures}

Synthetic methodologies provide routes for creating peptide sequences that are useful in the formation of supramolecular nanostructures $[44,45]$. These peptides include amino acid residues carrying specific information on their side chains such as hydrophilicity, hydrophobicity and chirality. Hydrophobic and hydrophilic residues affect peptide assemblies through the formation of $\beta$-sheet and $\alpha$-helix secondary structures [16].

\section{$\alpha$-Helical based nanostructures}

$\alpha$-Helices are the most common form of regular secondary structure of proteins. The $\alpha$-helical assemblies tend to be more reversible than the $\beta$-sheet units. Several $\alpha$-helical based nanostructures have been designed for 


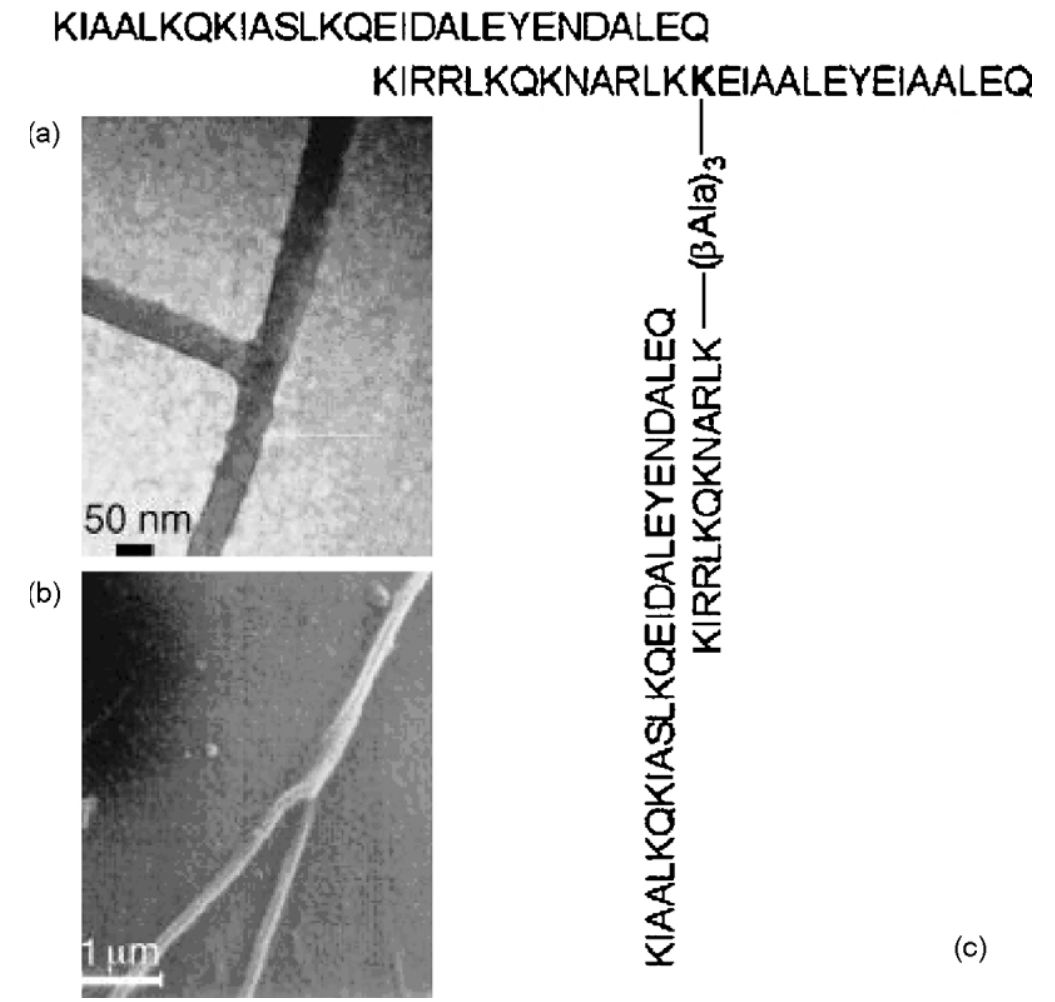

Figure 2 (a) TEM image of a self-assembling branched peptide. (b) SEM image of a self-assembling branched peptide. (c) Selfassembled fiber peptide building blocks of linear and branched fibers. Reproduced with permission from Ref. [46].

the construction of systems with engineering biological activity.

Coiled-coil peptides are an example of supramolecular structures that can be used to present functional epitopes in high density [46]. Coiled-coil structural motifs produced by the helical peptides form self-assembled filaments, as shown in Fig. 2.

Coiled-coils are widely used in folding motifs consisting of 2-5 helices that are wrapped around each other in a superhelical fashion. A heptad periodicity in the amino acid sequence, $-\mathrm{a}-\mathrm{b}-\mathrm{c}-\mathrm{d}-\mathrm{e}-\mathrm{f}-\mathrm{g}-$, is used to form the coiledcoil structures [47] (Fig. 3). In this case, hydrophobic amino acids are inserted in the ' $a$ ' and ' $d$ ' positions. The amino acids at positions ' $a$ ' and ' $d$ ' and ' $e$ ' and ' $g$ ' determine the aggregation number of the coiled-coil structure and the relative orientation of the constituent helices, respectively. In addition, electrostatic interactions are also used to develop reversible peptide assemblies. Coiled-coil nanostructures have been used to form hydrogels with potential uses as in situ depots for protein delivery [48].

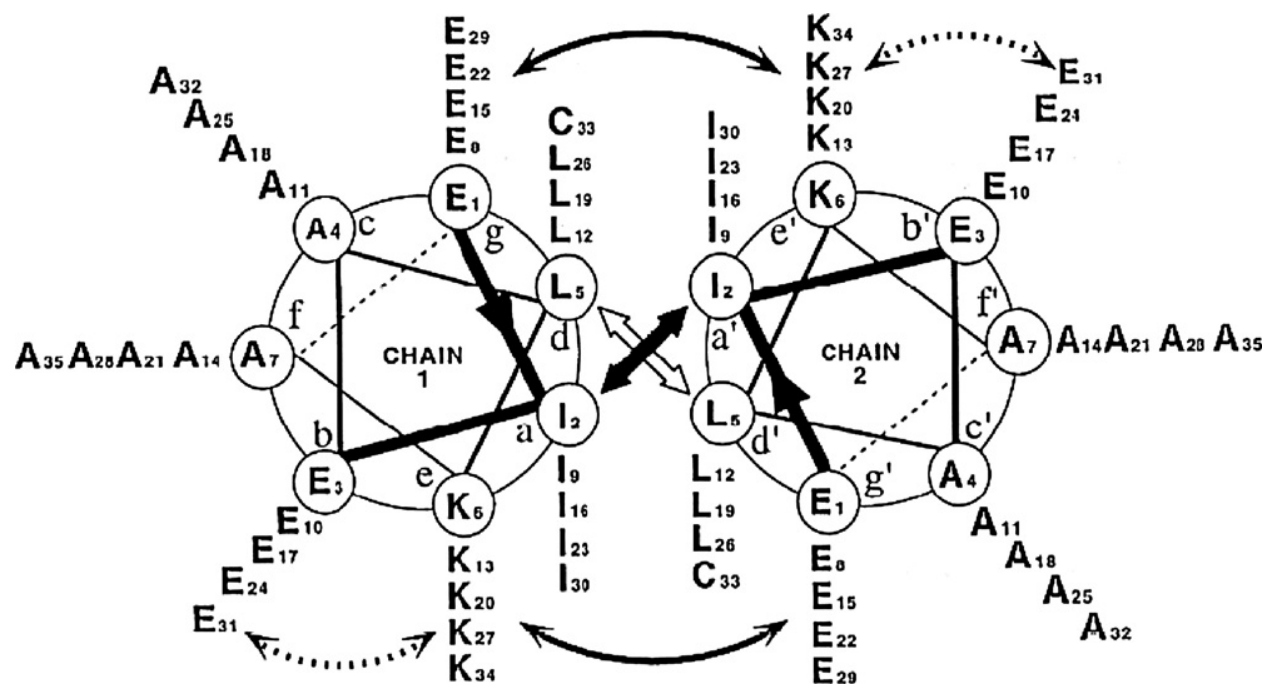

Figure 3 The amino acid organization in coiled-coil helical peptide formation. Reproduced with permission from Ref. [47]. 
In the case where the interacting surface between the helices contains leucine, the structure is called a 'leucine zipper'. Various research groups designed leucine zippers for nanostructures with different properties $[49,50]$. O'Shea et al. were the first to propose a design in which one strand with acidic residues and the other with basic residues yields a parallel heterodimer, named as 'Peptide Velcro' [49]. An asparagine residue, which is uncharged, is buried inside and this contributes to the specificity of the helix orientation and oligomerization state. Simple sequences can be designed to have a very high preference to pair with each other, so the 'Peptide Velcro's could be utilized to bring two molecules together, either in vitro for sensing applications or in cell.

Ryadnov et al. designed a system, called 'belt-andbraces', where two peptides (braces) are bound together by a third peptide (belt) of opposite charge [50]. A sixheptad design was adopted for the belt and braces, with the braces having three heptads each. The peptides were designed such that braces were directed to opposite ends of the belt, so that the braces could be functionalized at their termini of interest. Braces coupled with colloidal gold nanoparticles required the addition of the belt in order to form nanoscale networks, claimed to be the first example of peptide-mediated nanoparticle assembly.

\section{$\boldsymbol{\beta}$-Sheets based nanostructures}

The $\beta$-sheet is the second common form of regular secondary structure in proteins consisting of $\beta$-strands, which are connected laterally by three or more hydrogen bonds, forming a twisted, pleated sheet. A $\beta$-sheet unit has extensive hydrogen bonding between the carbonyl oxygen of an amino acid in one strand and the nitrogen of a second amino acid in another strand. The hydrogen bonding, along with the contribution of hydrophobic effects, stabilizes the $\beta$-sheets. $\beta$-Sheets can be either parallel, two $\beta$-sheet units aligned in the same direction from one terminus to the other, or antiparallel, the units aligned in the opposite direction. Recent research has focused on the role of $\beta$-sheet-rich fibrillar structures in neurodegenerative diseases such as Alzheimer's, Parkinson's, Creutzfeldt-Jakob's diseases in humans, and bovine spongiform encelophalopathy and scrapie in animals [51-57]. The ability to design $\beta$-sheet nanostructures to self-assemble into amyloid-like fibrils, where the fundamental unit of amyloid fibrils is found to be a steric zipper formed by two tightly interdigitated $\beta$-sheets [58], has helped researchers to understand the folding and pathogenesis mechanisms better, and enabled the generation of new biomaterials with interesting properties [59-64].

Based on the structure of a natural $\beta$-barrel protein, the $\alpha$-hemolysin pore of $S$. aureus [65] inspired the construction of synthetic self-assembling molecules to form $\beta$-barrels by using $\beta$-sheets. Rigid-rod $\beta$-barrels based on assembly of octa(p-phenylene)s were synthesized with $\alpha$-peptide side chains interdigitated with side chains of adjacent staves [66] (Fig. 4). Turning the $\beta$-barrels inside out enables the barrels to form synthetic pores in membrane bilayers. Synthetic, multifunctional pores can be used as specific and selective enzyme sensors $[67,68]$. In addition to structures that mimic $\beta$-barrels, another approach to forming helical pore structures has been through the use of amphiphilic dendritic dipeptides [69]. The porous structure of the assembled pores enabled proton translocation at a rate similar to gramicidin channels. Barrel proteins and $\beta$-helices formed by gramicidin A are mainly formed by the $\beta$-sheet hydrogen bonding structures [70]. The $\beta$-sheet hydrogen bonding with a degree of curvature results in formation of aggregated nanostructures [71,72] (Fig. 5).

Another example of $\beta$-sheet containing nanostructures are self-assembling macrocycles containing an even number of alternating D- and L-amino acids [73-75]. Strong hydrogen bonding between the individual macrocycles yields high-aspect-ratio nanostructures containing twodimensional $\beta$-sheets. The inner diameter of the peptide nanotubes is controlled by the number of amino acids in the macrocycle [76]. Structures based upon macrocycles have been used as antibacterial agents, which act by solubilizing or disrupting the bacterial membrane [75,77] (Fig. 6).

\section{Amphiphilic peptides based nanostructures}

Amphiphilic peptides consist of a hydrophilic peptide headgroup and a hydrophobic alkyl tail where the headgroup incorporates a bioactive sequence and the tail has a role to align the headgroup, promote self-assembly, and induce desirable secondary, super-secondary and tertiary conformations [78-82]. The self-assembly leading to different
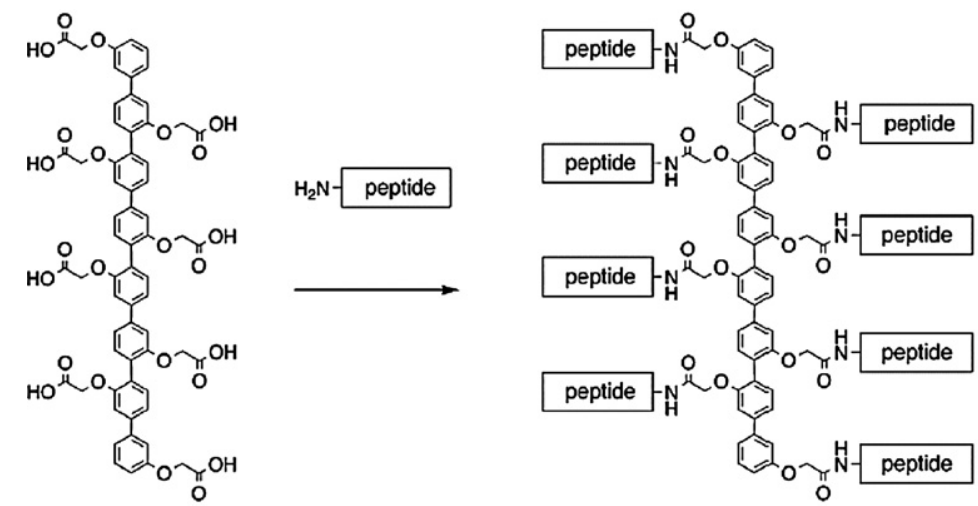

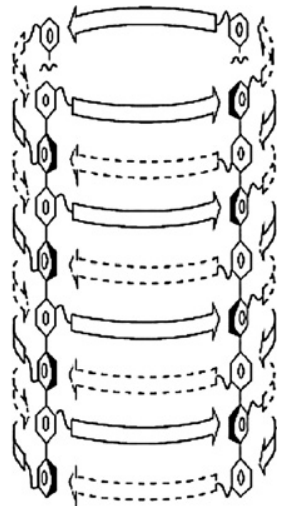

Figure 4 Tripeptide-based self-assembling amphiphilic molecule. Reproduced with permission from Ref. [66]. 


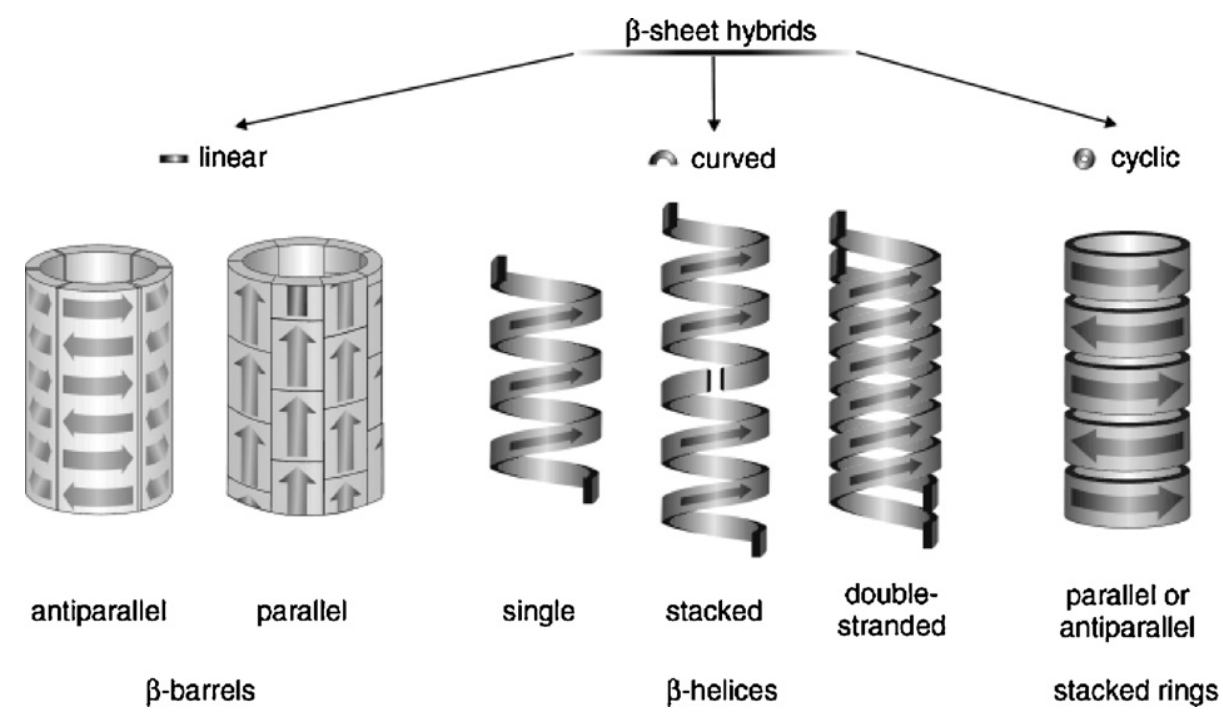

Figure 5 Nanotubes derived by $\beta$-sheet forming molecules. Reproduced with permission from Ref. [71].

structures is related to standard free energy change during aggregation. The concept of opposing forces of Tanford, hydrophobic attractions at the water-hydrocarbon interfaces and the hydrophilic, ionic or steric repulsion between the headgroups, was the first explanation for growth and shape of surfactant aggregates [83]. Although Tanford forces had originally been devised for lipid molecules, it can be applied to amphiphilic molecules, including amphiphilic peptides. However, Tanford forces may not be sufficient to explain all amphiphilic peptide aggregations [84]. The molecular packing parameter $(p)$, determining the final shape, is defined as $V_{o} / A_{0} l_{c}$, where $V_{o}$ is the volume occupied by tail, $l_{c}$ is the critical tail length and $A_{o}$ is the optimal area per headgroup. For $p<1 / 3$, spherical micelles are favored; for $p$ between $1 / 3$ and $1 / 2$, cylindrical micelles are favored; for $p$ between $1 / 2$ and 1 , flexible bilayers and vesicles are favored [85]. For many amphiphilic peptides, the packing parameter is between $1 / 2$ and 1 ; but instead of bilayers, nearly all form cylindrical structures. According to Tsonchev et al., the mechanism of self-assembly of amphiphilic peptides is not only composed of hydrophobic interactions, but also contains electrostatic interactions [84]. The formation

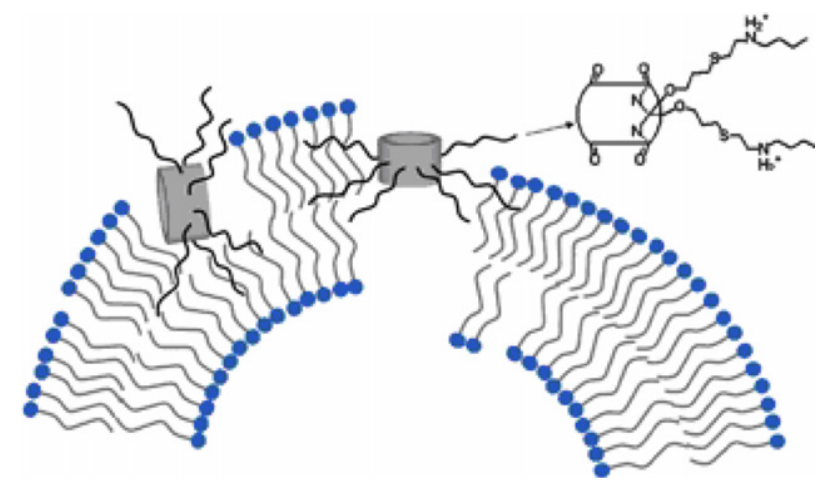

Figure 6 A bacterial membrane model: the annihilation mechanism of macrocycles as antibacterial agents. Reproduced with permission from Ref. [77]. of a $\beta$-sheet due to hydrogen bonding between the peptide parts of the molecules plays also an important role in the self-assembly. Unlike spherical micelles, the hydrophilic headgroups of cylindrical micelles are attractive. The strong directional electrostatic interactions of headgroups competed with attractive hydrophobic interactions of tails under the conditions of a pH between 2 and 4, where in the case of amphiphilic peptides, the winner was the electrostatics. The Monte Carlo simulations showed that the final structure was spherical in the absence of electrostatic interactions.

A more recent study on the self-assembly mechanism of peptide amphiphiles by Velichko et al. revealed that the hydrogen bonding is the main interaction contributing to the final shape [86]. They modelled the headgroups as electroneutral, meaning that the acidic peptide amphiphiles form fibers under acidic conditions and basic peptide amphiphiles under basic conditions in order not to calculate the effects of electrostatics in the self-assembly process. Therefore, the Monte Carlo-stochastic dynamics simulations can be done in a reasonable time while capturing various aspects of the process. According to their coarse-grained model, transitions from random molecules in solution to different micellar structures are based on the interaction between hydrophobic interactions and hydrogen bonding.

Amphiphilic peptides are developed to form nanostructures for various applications in many areas of nanotechnology. Simple structures inspired from the $\beta$ amyloid core motif, dipeptides formed by phenylalanines, have been shown to form nanotubes in aqueous solutions [87]. Amyloid-forming peptides with metal binding capacity have found applications as templates for the fabrication of low resistance, conducting nanowires $[8,88]$. Cysteine residues acted as nucleation sites for deposition of metal on the protein, also serine amino acids deposited platinum and gold nanoparticles. Gazit and co-workers also compared the antiamyloidogenic action mechanism of phenolsulfonphthalein to phenolphthalein [89]. Understanding the amyloid fibril assembly mechanism better might help during the design process of antiamyloidogenic inhibitors; as amyloidogenesis is related to many neurodegenerative 
diseases, designing molecules with inhibitor potency is very important. Although the primary structure of these two molecules is very similar, their 3D structures differ from each other, resulting in different inhibitory potentials. Phenolsulfonphthalein has been shown to be a very influential inhibitor for amyloid fibril formation whereas phenolphthalein did not show any significant activity. Other molecules designed by Gazit et al. with antiamyloidogenic activity include indole-based molecules [90], peptides modified with $\alpha$-aminoisobutyric acid sequence as $\beta$ breaker [91], and polyphenols [92].

Ulijn and co-workers designed amphiphilic peptides with a 9-fluorenylmethoxycarbonyl (Fmoc) group and a diphenylalanine dipeptide [93]. The Fmoc dipeptides, composed of combinations of 4 different amino acids, namely glycine, alanine, leucine and phenylalanine, have been shown to form hydrogels with different structural and physical properties depending on the amino acid composition of the peptide building blocks. By incorporating a basic amino acid (lysine) into the mixture, hydrogels stable at physiological $\mathrm{pH}$ could be formed. These hydrogels are composed of nanostructures similar to the fibrillar components of extracellular matrix $(E C M)$ as mechanical support for cells. The hydrogels were manufactured into solid biocompatible molds for drug encapsulation and controlled drug release; also, they have been shown to be suitable as scaffolds for cell growth in two and three dimensions. In a later study, Fmoc protected ArgGly-Asp (RGD) peptide building blocks have been shown to form hydrogels and to promote adhesion of human dermal fibroblasts through specific RGD-integrin binding, with subsequent cell spreading and proliferation [94]. One important aim in the design of synthetic tissue scaffolds is to mimic the structure and function of the extracellular matrix providing a cellular microenvironment with characteristics similar to those encountered in vivo. The ECM organizes cells into tissue, affects overall cellular architecture, provides pathways for migratory cells, participates in signal transduction pathways and strengthen tissues. Therefore, while designing a scaffold, biodegradability and mechanical properties must be taken into consideration besides addition of growth factors and functionalization of the scaffold with short amino acid sequences that mimic the adhesion domains of ECM. In some cases, scaffolds which degrade fast and release the bioactive molecules are desirable, in other cases one might wish to have a slowly degrading scaffold which maintains its integrity and structure for a longer time. If the scaffold is going to be used for a load-bearing tissue, especially during the early growth phase, sufficient temporary mechanical integrity for the scaffold is required to withstand the in vivo stress and loading.

Bolaamphiphiles are another class of amphiphilic molecules that have hydrophilic groups at both ends of a hydrocarbon chain [95]. Introduction of a second headgroup to single-headed amphiphiles has been shown to induce a higher solubility in water [96]. Synthetic unsymmetrical bolaamphiphiles developed by Claussen et al. contain (L-glutamyl) , $_{3}$-glycine at one terminus and either tetraethylene glycol or aspartic acid at the other [97]. The peptidic segment of the bolaamphiphile undergoes $\beta$ sheet hydrogen bonding to form various supramolecular nanostructures; bolaamphiphiles that give rise to structures such as fibers, rods, tubes, ribbons, and spheres have been developed [97-102]. Bolaamphiphile nanotubes have been implemented as viral assays [103] even when the pathogens are label-free [104], and for protein sensing [105], among other interesting applications.

Zhang et al. revealed that alternating hydrophilic and hydrophobic amino acids of a region of the Z-DNA binding zuotin protein [106] could be used to form nanofibers, where the alternating residues induce a stable $\beta$-sheet structure. Ellis-Behnke et al. used a similar class of peptide nanofibers to regenerate axons to reverse vision loss in rodents to correct central nervous system problems [107]. Self-assembling peptide nanofiber scaffolds were modified at the amino terminal with sequences derived from collagen IV or laminin I [108]. Addition of these sequences has enhanced the adhesion and spreading rate of human aortic endothelial cells. In another study, the peptide nanofibers were combined with epithelial growth factor, mimicking the structure and porosity of ECM to improve the rate of wound healing on human skin equivalent tissue model [109]. Such modified scaffolds have been shown to be useful as cell cultures for mouse neural stem cells [110] and pre-osteoblast cells [111]. The nanofibers developed by Zhang et al. can be applied by injecting into myocardium, creating an intramyocardial microenvironment for mouse endothelial cells that promotes vascular cell recruitment [112].

Peptide amphiphile molecules forming different types of nanofibers were developed by Hartgerink et al. [113]. The supramolecular sheets have a tendency to hide hydrophobic segments from water and collapse into cylindrical nanostructures [113] (Fig. 7). These peptide amphiphile molecules were designed with biologically active peptides responsible for cell adhesion. Cysteine residues were used to stabilize the aggregate by means of cross-linking. The phosphorylated serine residue was used to interact with calcium ions for mineralization of hydroxyapatite. The net charge of the system keeps molecules dissolved in water as a result of coulombic repulsion. Neutralization of the charged groups triggers the self-assembly process that includes the hydrogen bond formation among the peptide sequences. As the nanofibers grow, they bundle and form a network in water, which results in self-supporting gel formation. An arginine-glycine-aspartic acid (RGD) peptide sequence, playing a role in integrin-mediated cell adhesion, was integrated into the structure. Linear and cyclic RGDS sequences were also presented on N-terminal of peptide amphiphile nanofibers [114], where not only RGDS but also other bioactive signals were used such as biotin [115]. In case the nanofibers assemble from branched peptide amphiphiles, the branched covalent architecture leads to greater accessibility of binding sites. This class of self-assembled nanostructures were developed as bioactive scaffolds for enhanced epitope recognition to improve cell adhesion event [114,116], for tissue engineering applications [117,118] and magnetic resonance imaging in a bound form to contrast agents [119]. Sargeant et al. fabricated hybrid bone implants, where peptide amphiphile nanofibers were self-assembled within porous titanium [120]. Their results demonstrated cell encapsulation in the implants, vascularization around the implant, and mineralization of calcium phosphate with a $\mathrm{Ca}: \mathrm{P}$ ratio similar to that of hydroxyapatite, a calcium phosphate mineral. Their strategy could be tailored to induce new 

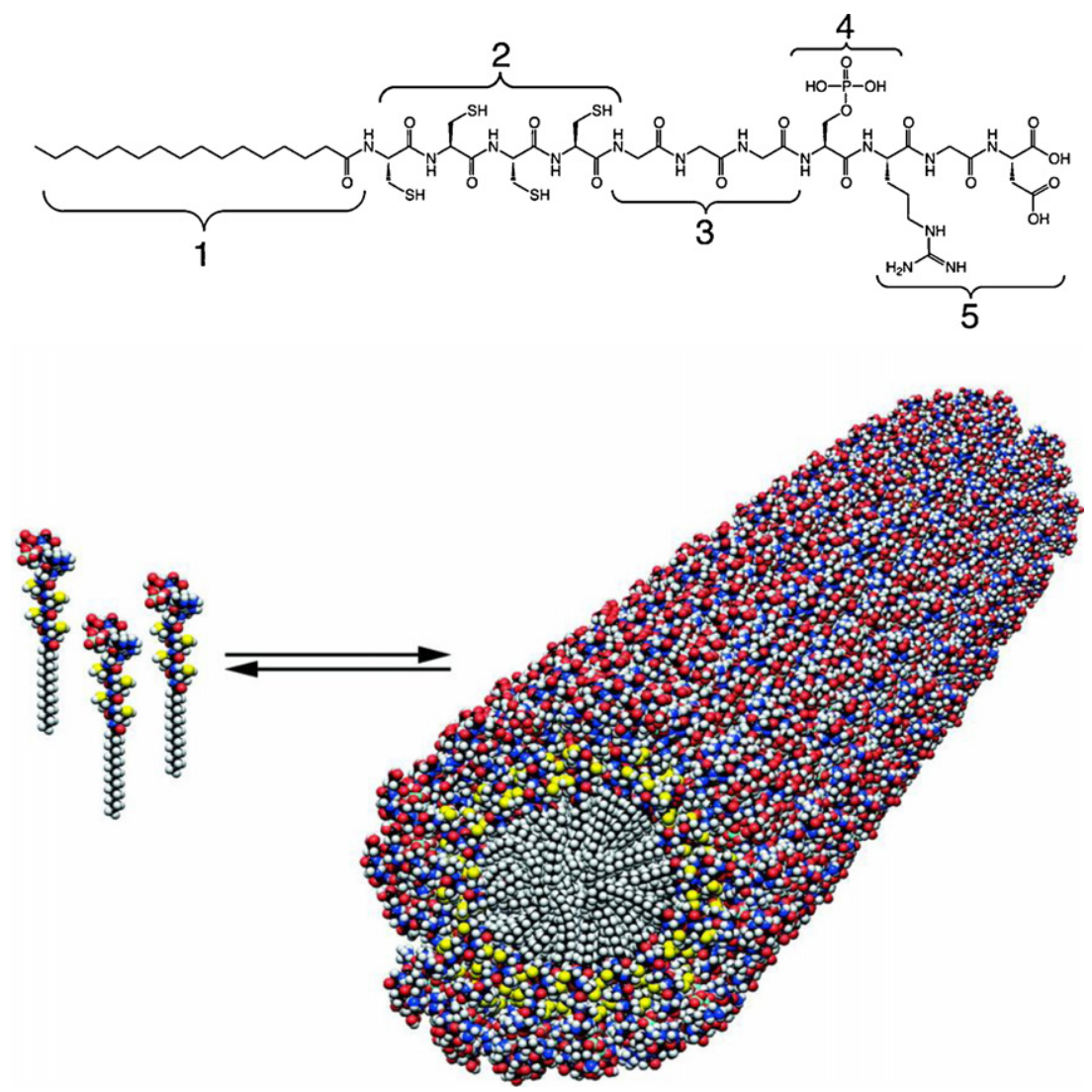

Figure 7 Peptide amphiphile chemical structure demonstrating, alkyl tail (1), consecutive cysteine residues (2), flexible linker region of three glycine residues (3), a single phosphorylated serine residue (4) and cell adhesion ligand RGD (5). Reproduced with permission from Ref. [113].

bone formation and improve thereby fixation, osteointegration and long-term stability of implants. There are various applications of self-assembling nanofibers as scaffolds for neural progenitor cells [2], dental stem cells [121], for cell entrapment [122], and to stimulate angiogenesis [123].

Aulisa et al. designed peptide amphiphile molecules targeted against proliferation of cancer cells [124]. The concentration of peptide amphiphiles was chosen low in order to form spherical micelles. The concentration at which peptide amphiphiles are used determines the final structure. Above its critical micelle concentration, a single tail peptide amphiphile molecule at high concentration assembles into nanofibers, whereas low concentrations result in micelle formation. The design mimics a hexapeptide motif of HOX gene, a subgroup of homeobox genes found in clusters on the genes of vertebrates and playing a role in directing embryonic development, and inhibits the HOX/PBX complex formation, thereby preventing DNA transcription.

Schneider et al. designed a 20 amino acid long peptide, MAX1, which consists of two $\beta$-strands with alternating valine and lysine residues connected via a type II' $\beta$ turn. MAX1 first folds into $\beta$-hairpin structure under basic conditions and then self-assembles into hydrogel $[125,126]$ (Fig. 8). The $\beta$-hairpin hydrogel promotes the growth and proliferation of fibroblast cells [127] and has been shown to be effective against prevalent hospital bacteria [128].
Hydrogels prepared from MAX1 and MAX8 were useful for encapsulating and releasing model biomacromolecules in a controllable fashion [129]. MAX1 and MAX8 are same except a point substitution on the hydrophilic face of the hairpin where a lysine in MAX1 is substituted by a glutamic acid in MAX8. This substitution changed the overall charge state of the peptide at physiological $\mathrm{pH}$. Also, the glutamic acid of MAX8 repelled the circumjacent negatively charged groups. Both mesh size and electrostatics between the gel network and macromolecule have been shown to influence macromolecular mobility within the gel network. By changing the peptide weight percent and the amino acid sequence, it is possible to control the mesh size and consequently the probe diffusion and release rate of macromolecules from the $\beta$-hairpin peptide hydrogels.

Amphiphilic peptides have also found applications in drug delivery $[130,131] . \alpha, \beta$-Dehydrophenylalanine residues containing amphiphilic dipeptides, $\mathrm{H}-\mathrm{Glu}-\Delta \mathrm{Phe}-\mathrm{OH}$ and $\mathrm{H}$ Lys- $\Delta$ Phe-OH, self-assemble into nanovesicles and can contain small molecules such as vitamins, peptides and small proteins. The advantages of using nanovesicles are that they are resistant against proteases, are stable and do not show cytotoxicity in cell culture conditions [130]. For drug delivery, $\beta$-sheet nanoribbons have been used as well. A cyclic Arg-Gly-Asp (RGD) peptide segment has been added to a $\beta$-sheet forming peptide segment, which selfassembled into a nanoribbon structure [132] (Fig. 9). This 


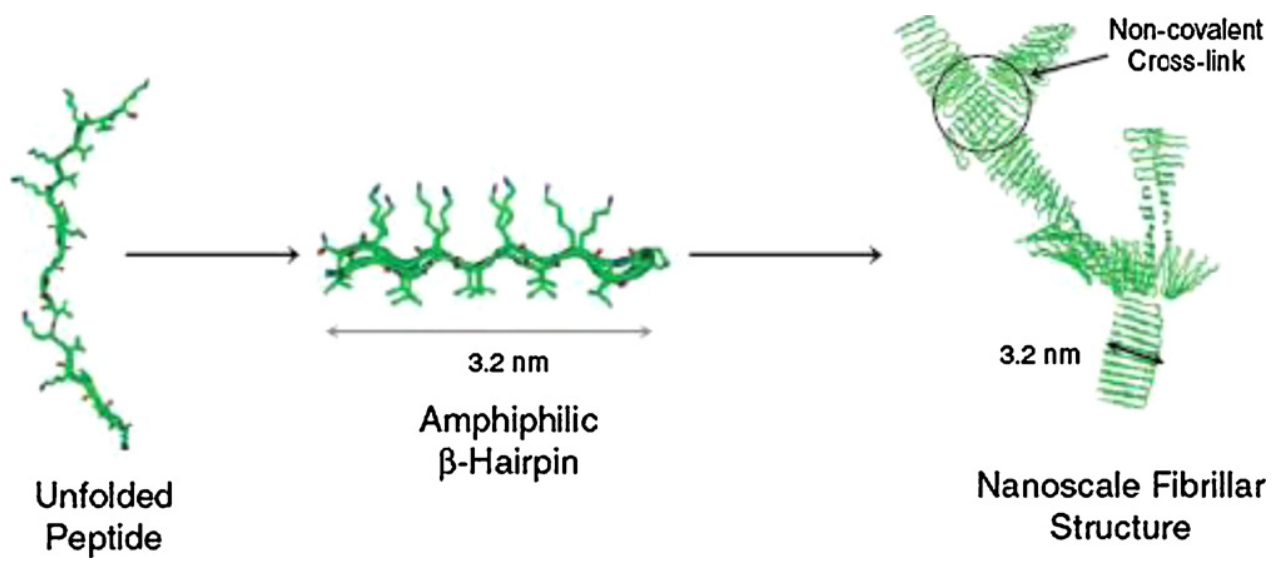

Figure 8 Model for the folding and self-assembly of MAX1. Reproduced with permission from Ref. [126].

nanoribbon has been shown to encapsulate hydrophobic molecules and be internalized into cells through integrin receptors.

Using $\beta$-sheet peptide-based nanoribbons as building blocks, filament-shaped artificial viruses for gene and drug delivery have been designed [133]. The hydrophobic and electrostatic interactions produced by the tryptophanlysine-tryptophan-aspartic acid repeats in the $\beta$-sheet peptide segment promote the formation of nanoribbons by self-assembly of $\beta$-sheet peptides. It has been shown that for gene delivery, siRNA, a double-stranded RNA that is 21-23 nucleotides in length and induces RNA interference, could be encapsulated within the carbohydrate surfaces without disordering the discrete nanoribbon structure [133].
Another use of nanoribbons, containing a carbohydrate and a polyethylene glycol spacer, has been in the area of controlling bacterial motility and agglutination [134]. It has been proven that the spacer length must have a sufficient length in order to stabilize the nanoribbon structure, which increased the efficiency of the nanoribbon to inhibit motility and agglutination of bacteria.

Tirrell and Fields developed amphiphilic peptides modified at the N-terminal with monoalkyl [78] or dialkyl [135] hydrocarbon chains, demonstrating the effect of lipid tails on stabilization of desired molecular structures during formation of triple helices, a structure found in collagen. Lipidation of peptides also induced the formation of $\alpha$ helical structures $[79,81]$. These nanostructures have been

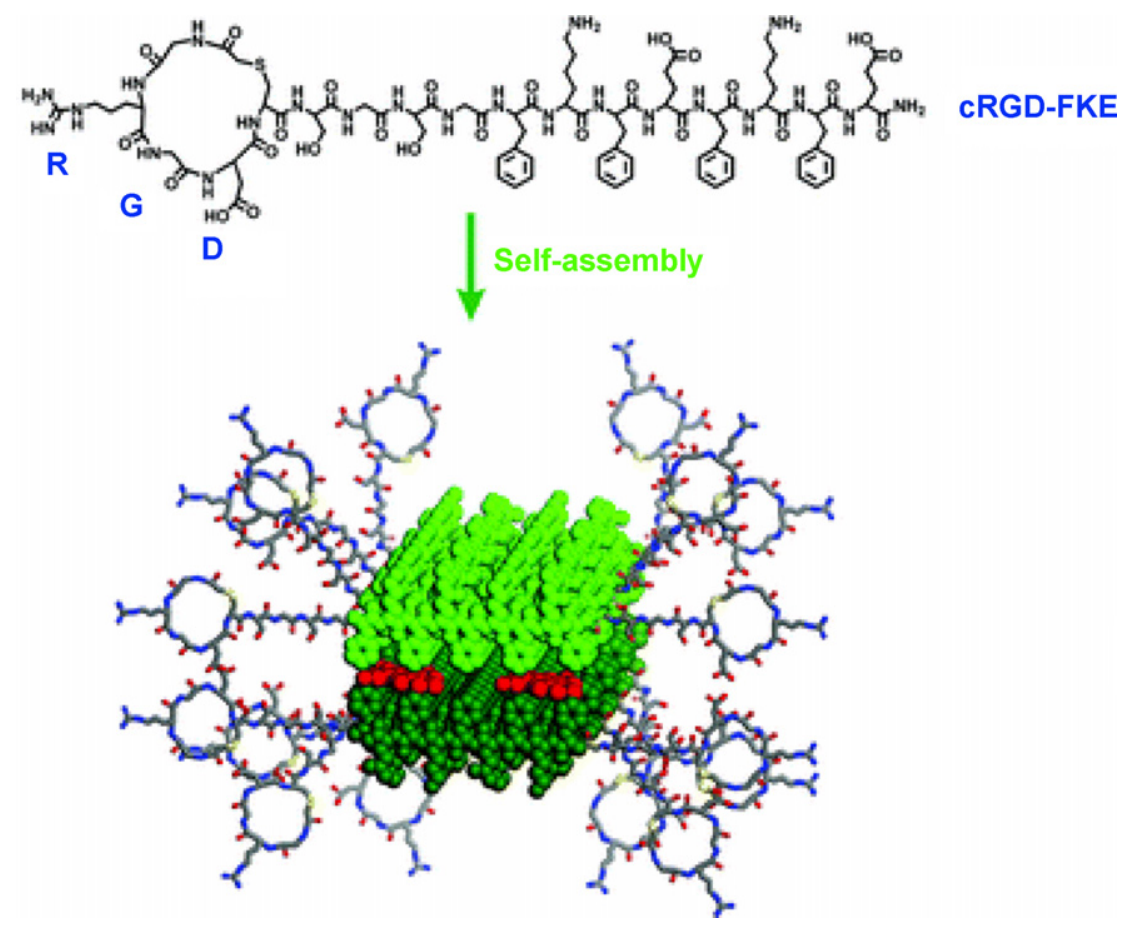

Figure 9 Self-assembly of the nanoribbon by a cyclic RGD segment, a flexible linker segment (Ser Gly-Ser-Gly) and a $\beta$-sheet forming peptide segment (Phe-Lys-Phe-Glu-Phe-Lys-Phe-Glu: FKE). Reproduced with permission from Ref. [132]. 


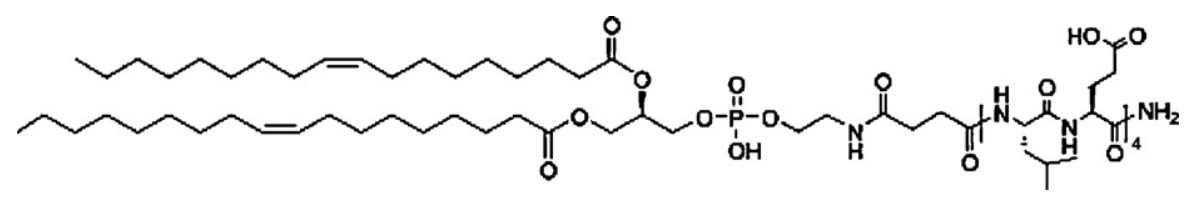

Figure 10 Amphiphilic lipopeptide to form a $\beta$-sheet structure. Reproduced with permission from Ref. [136].

shown to promote adhesion and spreading of melanoma cells [81]. Cavalli et al. formed an amphiphilic lipopeptide, to form antiparallel $\beta$-sheets, by combining the water-soluble (Leu-Glu) ${ }_{4}$ octapeptide with a phospholipid moiety [136] (Fig. 10). The self-organizing $\beta$-sheet template was developed to mineralize calcium carbonate.

\section{Collagen-like peptides}

Collagen, providing the structural and organizational framework for cartilage, bone, tendon, blood vessels, skin, and fascia, is the essential structural component of the connective tissue. Collagen consists of three left-handed alpha chains that are supercoiled around a common axis to form a right-handed superhelix, called "triple helix". Every third residue of the helix points inwards, sterically where only glycine fits. A frequent motif found in the triple helix is Glycine- $Y-X$. $X$ and $Y$ can be the imino acids proline or hydroxyproline, but hydroxyproline contributes more stability at the $Y$ position due to the stereoelectronic promotion of the more favorable exo ring pucker and forming hydrogen bonds with water molecules surrounding the triple helix $[137,138]$. In collagen diseases, a change of a single glycine into another amino acid with a larger side chain is not uncommon $[139,140]$.

The triple helix constitutes a rod-like structure important for fibril formation and structural integrity; it also interacts with a wide range of molecules important in extracellular matrix organization and function. Natural collagen has been used for various biomedical applications $[27,31,141-143,145]$; however, there are risks [146-149] of using natural products such as contamination with prions, viruses or some other molecules and allergic reactions. As a result, collagen-like model peptides that would form triple helices and self-assemble into supramolecular fibrils have been developed with potential uses as biomaterials [33-36,144,150,151]. The best characterized and most common collagen form is the D-periodic fibril, observed as the major structural component in tendon, skin and most other connective tissues. Rele et al. developed a collagen-mimetic peptide, NH-(Pro-Arg-Gly) ${ }_{4}$-(Pro-HypGly) ${ }_{4}$-(Glu-Hyp-Gly) ${ }_{4}-\mathrm{COOH}$ (CPII), in which the sequence was designed to exhibit linear fibril growth upon assembly of the triple-helical structure into D-periodic microfibrils [152]. (Pro-Hyp-Gly) ${ }_{4}$ sequence formed a hydrophobic core, which facilitated the preferred linear oligomerization within a fibril and staggered orientation between adjacent fibrils. Even at low concentrations and neutral pH, the oligopeptide showed a high propensity for self-association following a nucleation-growth mechanism.

Fields et al. have developed collagen-like peptide amphiphiles [135,153]. A triple-helical polypeptide of 124 amino acids, where Gly-Pro-Hyp triplets induced triple helic- ity, incorporated residues 1263-1277 of alpha 1 (IV) collagen to which highly metastatic mouse melanoma cells were shown to adhere [154].

Bioadhesive surfaces incorporating triple-helical collagen-mimetic peptides of the hexapeptide sequence GFOGER from residues 502-507 of the $\alpha 1$ (I) chain of type I collagen were engineered to exhibit specificity for the integrin receptor $\alpha 2 \beta 1$ and focal adhesion formation, with an ultimate aim to control intracellular signaling and cell function [155].

Collagen-mimetic peptides supplemented with the GFOGER sequence and the EDGFFKI and APQQEA substrate sequences were conjugated onto a dendrimer, resulting in a cross-linkable collagen-mimetic dendrimer [156]. The dendrimer was used as a template to enhance intramolecular folding thus stabilizing the triple-helical structures. The GFOGER cell-binding sequence was sandwiched between the structural domains, repeating Gly-Pro-Hyp triplets, whereas the APQQEA or the EDGFFKI sequences were placed at the extension of the $\mathrm{C}$-termini of the collagen-mimetic peptides.

\section{Conclusions}

Self-assembly is an important part of natural materials design. Nature can build thousands of nanostructures from 20 amino acids. So, through using the nature as a guide to understand the interactions and forces in molecular self-assembly, it has become possible to mimic the natural processes in order to produce numerous well-defined nanoscale objects. Several self-assembling peptidic nanostructures have been developed, ranging from designs to study protein folding to nanoscale assemblies including nanotubes, nanovesicles and nanofibers.

Self-assembly is a bottom-up technology with many advantages over top-down approaches, including threedimensional assembly, versatility, cost-effective large-scale production, and achievement of near-atomic feature size. Self-assembly into desired structures occurs through molecular recognition, wherein the non-covalent interactions between two molecules are both energetic and specific. These interactions consist of hydrogen bonding, electrostatic, hydrophobic and aromatic interactions. The level of interaction is defined by all these effects balanced against the tendency toward entropic disorder.

Different molecular entities can be used in the selfassembled materials; however, peptides are particularly attractive as building blocks because they are chemically versatile, biodegradable, biocompatible, and can be manipulated to adopt different secondary structures. Self-assembling nanostructures based on biological macromolecules are interesting because of their potential chemical and structural diversity. Functionalizing nanostructures has been achieved by incorporation of various 
biologically active structures. Thereby, molecular selectivity, specificity and activity in self-assembled nanostructures are promoted. The physical and chemical mechanisms underlying the assembly of these nanostructures are still developing and many potential biological applications are yet to be fully realized. Self-assembling peptides will yield vast opportunities in developing new functional biomaterials in near future.

\section{Acknowledgements}

Authors thank Dr. James Hulvat for helpful discussions and also thank Can Koral for his help in graphics. MOG is supported in part by the Marie Curie IRG under grant number 231019.

\section{References}

[1] J.J. Hwang, S.N. Iyer, L.-S. Li, R. Claussen, D.A. Harrington, S.I. Stupp, Proc. Natl. Acad. Sci. U. S. A. 99 (2002) 9662.

[2] G.A. Silva, C. Czeisler, K.L. Niece, E. Beniash, D.A. Harrington, J.A. Kessler, et al., Science 303 (2004) 1352.

[3] M. Metzke, S. Maiti, E. Nelson, Z. Guan, Angew. Chem. Int. Ed. 44 (2005) 6529.

[4] K.Y. Lee, E. Alsberg, S. Hsiong, W. Comisar, J. Linderman, R. Ziff, et al., Nano Lett. 4 (2004) 1501.

[5] Y. Jin, N. Friedman, M. Sheves, T. He, D. Cahen, Proc. Natl. Acad. Sci. U. S. A. 103 (2006) 8601.

[6] S.T. Nguyen, D.L. Gin, J.T. Hupp, X. Zhang, Proc. Natl. Acad. Sci. U. S. A. 98 (2001) 11849.

[7] S.R. Forrest, Nature 428 (2004) 911.

[8] T. Scheibel, R. Parthasarathy, G. Sawicki, X.-M. Lin, H. Jaeger, S.L. Lindquist, Proc. Natl. Acad. Sci. U. S. A. 100 (2003) 4527.

[9] C. Sanchez, H. Arribart, M.M. Giraud Guille, Nat. Mater. 4 (2005) 277.

[10] J.W. Steed, Supramolecular Chemistry, Wiley, Chichester, 2000.

[11] S.I. Stupp, V. LeBonheur, K. Walker, L.S. Li, K.E. Huggins, M. Keser, et al., Science 276 (1997) 384.

[12] K.A. Jolliffe, P. Timmerman, D.N. Reinhoudt, Angew. Chem. Int. Ed. 38 (1999) 933.

[13] K.B. Thurmond, T. Kowalewski, K.L. Wooley, J. Am. Chem. Soc. 119 (1997) 6656.

[14] H.R. Marsden, A.V. Korobko, E.N.M. van Leeuwen, E.M. Pouget, S.J. Veen, N.A.J.M. Sommerdijk, et al., J. Am. Chem. Soc. 130 (2008) 9386.

[15] A.G. Ogston, Annu. Rev. Biochem. 24 (1955).

[16] D. Zanuy, R. Nussinov, C. Aleman, Phys. Biol. 3 (2006) S80.

[17] A. Lupas, Trends Biochem. Sci 21 (1996) 375.

[18] L. Pauling, R.B. Corey, H.R. Branson, Proc. Natl. Acad. Sci. U. S. A. 37 (1951) 205.

[19] F.H.C. Crick, Nature 170 (1952) 882.

[20] P.B. Harbury, J.J. Plecs, B. Tidor, T. Alber, P.S. Kim, Science 282 (1998) 1462.

[21] W. Landschulz, P. Johnson, S. McKnight, Science 240 (1988) 1759.

[22] P. Burkhard, J. Stetefeld, S.V. Strelkov, Trends Cell Biol. 11 (2001) 82.

[23] J. Liu, Q. Zheng, Y. Deng, C.-S. Cheng, N.R. Kallenbach, M. Lu, Proc. Natl. Acad. Sci. U. S. A. 103 (2006) 15457.

[24] E. Zerovnik, Eur. J. Biochem. 269 (2002) 3362.

[25] J.D. Sipe, A.S. Cohen, J. Struct. Biol. 130 (2000) 88.

[26] Y. Zhu, Z. Wu, Z. Tang, Z. Lu, J. Proteome Res. 1 (2002) 559.

[27] Z. Ruszczak, Adv. Drug Deliv. Rev. 55 (2003) 1595.

[28] J. Glowacki, S. Mizuno, Biopolymers 89 (2008) 338.
[29] L.A. Smith, P.X. Ma, Colloids Surf. B 39 (2004) 125.

[30] M. Maeda, S. Tani, A. Sano, K. Fujioka, J. Control. Rel. 62 (1999) 313.

[31] W. Friess, Eur. J. Pharm. Biopharm. 45 (1998) 113.

[32] T. Koide, Phil. Trans. Roy. Soc. B 362 (2007) 1281.

[33] K. Kar, P. Amin, M.A. Bryan, A.V. Persikov, A. Mohs, Y.-H. Wang, et al., J. Biol. Chem. 281 (2006) 33283.

[34] F.W. Kotch, R.T. Raines, Proc. Natl. Acad. Sci. U. S. A. 103 (2006) 3028.

[35] T. Gore, Y. Dori, Y. Talmon, M. Tirrell, H. Bianco-Peled, Langmuir 17 (2001) 5352.

[36] M.A. Cejas, W.A. Kinney, C. Chen, J.G. Vinter, H.R. Almond, K.M. Balss, et al., Proc. Natl. Acad. Sci. U. S. A. 105 (2008) 8513.

[37] A.T. Ansevin, M.A. Lauffer, Biophys. J. 3 (1963) 239.

[38] S.Y. Lee, E. Royston, J.N. Culver, M.T. Harris, Nanotechnology 16 (2005) S435.

[39] E. Royston, A. Ghosh, P. Kofinas, M.T. Harris, J.N. Culver, Langmuir 24 (2008) 906.

[40] R.A. Miller, A.D. Presley, M.B. Francis, J. Am. Chem. Soc. 129 (2007) 3104.

[41] L.M. Greig, D. Philp, Chem. Soc. Rev. 30 (2001) 287.

[42] A. Klug, Biosci. Rep. 3 (1983) 1573.

[43] T.L. Schlick, Z. Ding, E.W. Kovacs, M.B. Francis, J. Am. Chem. Soc. 127 (2005) 3718.

[44] T.J. Deming, Adv. Drug Deliv. Rev. 54 (2002) 1145.

[45] C.J. Hawker, K.L. Wooley, Science 309 (2005) 1200.

[46] M.G. Ryadnov, D.N. Woolfson, Angew. Chem. Int. Ed. 42 (2003) 3021.

[47] J.Y. Su, R.S. Hodges, C.M. Kay, Biochemistry 33 (1994) 15501.

[48] C. Xu, J. Kopeček, Pharm. Res. 25 (2008) 674.

[49] E.K. O’Shea, K.J. Lumb, P.S. Kim, Curr. Biol. 3 (1993) 658.

[50] M.G. Ryadnov, B. Ceyhan, C.M. Niemeyer, D.N. Woolfson, J. Am. Chem. Soc. 125 (2003) 9388.

[51] J.T. Nguyen, H. Inouye, M.A. Baldwin, R.J. Fletterick, F.E. Cohen, S.B. Prusiner, et al., J. Mol. Biol. 252 (1995) 412.

[52] J.R. Silveira, G.J. Raymond, A.G. Hughson, R.E. Race, V.L. Sim, S.F. Hayes, et al., Nature 437 (2005) 257.

[53] T. Wisniewski, M. Sadowski, BMC Neurosci. 9 (2008) S5.

[54] X. Lu, P.L. Wintrode, W.K. Surewicz, Proc. Natl. Acad. Sci. U. S. A. 104 (2007) 1510.

[55] S. Chimon, M.A. Shaibat, C.R. Jones, D.C. Calero, B. Aizezi, Y. Ishii, Nat. Struct. Mol. Biol. 14 (2007) 1157.

[56] P.T. Lansbury, Proc. Natl. Acad. Sci. U. S. A. 96 (1999) 3.

[57] L.C. Serpell, BBA-Mol. Basis Dis. 1502 (2000) 16.

[58] M.R. Sawaya, S. Sambashivan, R. Nelson, M.I. Ivanova, S.A. Sievers, M.I. Apostol, et al., Nature 447 (2007) 453.

[59] J.M. Smeenk, M.B.J. Otten, J. Thies, D.A. Tirrell, H.G. Stunnenberg, J.C.M. van Hest, Angew. Chem. Int. Ed. 44 (2005) 1968.

[60] K. Janek, J. Behlke, J. Zipper, H. Fabian, Y. Georgalis, M. Beyermann, et al., Biochemistry 38 (1999) 8246.

[61] O. Rathore, D.Y. Sogah, Macromolecules 34 (2001) 1477.

[62] G.T. Dolphin, P. Dumy, J. Garcia, Angew. Chem. Int. Ed. 45 (2006) 2699.

[63] W.H. Binder, O.W. Smrzka, Angew. Chem. Int. Ed. 45 (2006) 7324.

[64] A. Banerjee, S.K. Maji, M.G.B. Drew, D. Haldar, A. Banerjee, Tetrahedron Lett. 44 (2003) 699.

[65] L. Song, M.R. Hobaugh, C. Shustak, S. Cheley, H. Bayley, J.E. Gouaux, Science 274 (1996) 1859.

[66] N. Sakai, J. Mareda, S. Matile, Acc. Chem. Res. 38 (2005) 79.

[67] G. Das, P. Talukdar, S. Matile, Science 298 (2002) 1600.

[68] N. Sordé, S. Matile, Pept. Sci. 76 (2004) 55.

[69] V. Percec, A.E. Dulcey, V.S.K. Balagurusamy, Y. Miura, J. Smidrkal, M. Peterca, et al., Nature 430 (2004) 764.

[70] D.J. Chadwick, G. Cardew, Gramicidin and Related Ion Channel-forming Peptides, Wiley, Chichester, 1999. 
[71] M.A.B. Block, S. Hecht, Angew. Chem. Int. Ed. 44 (2005) 6986.

[72] M.A.B. Block, C. Kaiser, A. Khan, S. Hecht, Functional Molecular Nanostructures, Springer-Berlin, Heidelberg, 2005, 89 pp.

[73] N. Ashkenasy, W.S. Horne, M.R. Ghadiri, Small 2 (2006) 99.

[74] W.S. Horne, N. Ashkenasy, M.R. Ghadiri, Chem. Eur. J. 11 (2005) 1137.

[75] S. Fernandez-Lopez, H.S. Kim, E.C. Choi, M. Delgado, J.R. Granja, A. Khasanov, et al., Nature 412 (2001) 452.

[76] M.R. Ghadiri, J.R. Granja, R.A. Milligan, D.E. McRee, N. Khazanovich, Nature 366 (1993) 324.

[77] J. Choi, J. Kim, K. Kim, S.-T. Yang, J.-I. Kim, S. Jon, Chem. Commun. (2007) 1151.

[78] Y.-C. Yu, M. Tirrell, G.B. Fields, J. Am. Chem. Soc. 120 (1998) 9979.

[79] P. Forns, J.L. Lauer-Fields, S. Gao, G.B. Fields, Biopolymers 54 (2000) 531.

[80] R.S. Tu, M. Tirrell, Adv. Drug Deliv. Rev. 56 (2004) 1537.

[81] G.B. Fields, Y. Dori, P. Forns, Y.-C. Yu, M. Tirrell, Pept. Sci. 47 (1998) 143.

[82] H. Bianco-Peled, Y. Dori, J. Schneider, L.-P. Sung, S. Satija, M. Tirrell, Langmuir 17 (2001) 6931.

[83] Tanford, The hydrophobic effect: formation of micelles and biological membranes, Wiley-Interscience, New York (1973) viii.

[84] S. Tsonchev, G.C. Schatz, M.A. Ratner, J. Phys. Chem. B 108 (2004) 8817.

[85] J.N. Israelachvili, Intermolecular and Surface Forces, Academic Press Limited, London, 1992.

[86] Y.S. Velichko, S.I. Stupp, M.O. de la Cruz, J. Phys. Chem. B $112(2008) 2326$.

[87] M. Reches, E. Gazit, Science 300 (2003) 625.

[88] E. Kasotakis, E. Mossou, L. Adler-Abramovich, E.P. Mitchell, V.T. Forsyth, E. Gazit, et al., Pept. Sci. 92 (2009) 164.

[89] M. Levy, Y. Porat, E. Bacharach, D.E. Shalev, E. Gazit, Biochemistry 47 (2008) 5896.

[90] T. Cohen, A. Frydman-Marom, M. Rechter, E. Gazit, Biochemistry 45 (2006) 4727.

[91] S. Gilead, E. Gazit, Angew. Chem. Int. Ed. 43 (2004) 4041.

[92] Y. Porat, A. Abramowitz, E. Gazit, Chem. Biol. Drug Des. 67 (2006) 27.

[93] V. Jayawarna, M. Ali, T.A. Jowitt, A.F. Miller, A. Saiani, J.E. Gough, R.V. Ulijn, Adv. Mater. 18 (2006) 611.

[94] M. Zhou, A.M. Smith, A.K. Das, N.W. Hodson, R.F. Collins, R.V. Ulijn, et al., Biomaterials 30 (2009) 2523.

[95] R.M. Fuoss, D. Edelson, J. Am. Chem. Soc. 73 (1951) 269.

[96] B. Burczyk, Novel Surfactants: Preparation Applications And Biodegradability, Marcel Dekker Inc., New York, 2003, p. 129.

[97] R.C. Claussen, B.M. Rabatic, S.I. Stupp, J. Am. Chem. Soc. 125 (2003) 12680

[98] M. Kogiso, Y. Okada, T. Hanada, K. Yase, T. Shimizu, Biochim. Biophys. Acta 1475 (2000) 346.

[99] J.H. Fuhrhop, D. Spiroski, C. Boettcher, J. Am. Chem. Soc. 115 (1993) 1600.

[100] F. Qiu, Y. Chen, C. Tang, Q. Zhou, C. Wang, Y.-K. Shi, X. Zhao, Macromol. Biosci. 8 (2008) 1053.

[101] H. Matsui, G.E. Douberly, Langmuir 17 (2001) 7918.

[102] M.Z. Menzenski, I.A. Banerjee, New J. Chem. 31 (2007) 1674.

[103] R.I. MacCuspie, I.A. Banerjee, C. Pejoux, S. Gummalla, H.S. Mostowski, P.R. Krause, et al., Soft Matter 4 (2008) 833.

[104] R. de la Rica, E. Mendoza, L.M. Lechuga, H. Matsui, Angew. Chem. Int. Ed. 47 (2008) 9752.

[105] N. Kameta, M. Masuda, G. Mizuno, N. Morii, T. Shimizu, Small 4 (2008) 561.

[106] S. Zhang, C. Lockshin, A. Herbert, E. Winter, A. Rich, EMBO J. 11 (1992) 3787.

[107] R.G. Ellis-Behnke, Y.X. Liang, S.W. You, D.K.C. Tay, S.G. Zhang, K.F. So, et al., Proc. Natl. Acad. Sci. U. S. A. 103 (2006) 5054 .
[108] E. Genové, C. Shen, S. Zhang, C.E. Semino, Biomaterials 26 (2005) 3341.

[109] A. Schneider, J.A. Garlick, C. Egles, PLoS ONE 3 (2008) e1410.

[110] F. Gelain, D. Bottai, A. Vescovi, S. Zhang, PLoS ONE 1 (2006) 1.

[111] A. Horii, X. Wang, F. Gelain, S. Zhang, PLoS ONE 2 (2007) e190.

[112] M.E. Davis, J.P.M. Motion, D.A. Narmoneva, T. Takahashi, D. Hakuno, R.D. Kamm, et al., Circulation 111 (2005) 442.

[113] J.D. Hartgerink, E. Beniash, S.I. Stupp, Science 294 (2001) 1684.

[114] M.O. Guler, L. Hsu, S. Soukasene, D.A. Harrington, J.F. Hulvat, S.I. Stupp, Biomacromolecules 7 (2006) 1855.

[115] M.O. Guler, S. Soukasene, J.F. Hulvat, S.I. Stupp, Nano Lett. 5 (2005) 249.

[116] H. Storrie, M.O. Guler, S.N. Abu-Amara, T. Volberg, M. Rao, B. Geiger, et al., Biomaterials 28 (2007) 4608.

[117] Z. Huang, T.D. Sargeant, J.F. Hulvat, A. Mata, P. Bringas, C.-Y. Koh, et al., J. Bone Miner. Res. 23 (2008) 1995.

[118] D.A. Harrington, E.Y. Cheng, M.O. Guler, L.K. Lee, J.L. Donovan, R.C. Claussen, S.I. Stupp, J. Biomed. Mater. Res. Part A 78 (2006) 157.

[119] S.R. Bull, M.O. Guler, R.E. Bras, T.J. Meade, S.I. Stupp, Nano Lett. 5 (2005) 1.

[120] T.D. Sargeant, M.O. Guler, S.M. Oppenheimer, A. Mata, R.L. Satcher, D.C. Dunand, et al., Biomaterials 29 (2008) 161.

[121] K.M. Galler, A. Cavender, V. Yuwono, H. Dong, S. Shi, G. Schmalz, J.D. Hartgerink, R.N. D'Souza, Tissue Eng. Part A 14 (2008) 2051.

[122] E. Beniash, J.D. Hartgerink, H. Storrie, J.C. Stendahl, S.I. Stupp, Acta Biomater. 1 (2005) 387.

[123] K. Rajangam, H.A. Behanna, M.J. Hui, X. Han, J.F. Hulvat, J.W. Lomasney, et al., Nano Lett. 6 (2006) 2086.

[124] L. Aulisa, N. Forraz, C. McGuckin, J.D. Hartgerink, Acta Biomater. 5 (2009) 842

[125] J.P. Schneider, D.J. Pochan, B. Ozbas, K. Rajagopal, L. Pakstis, J. Kretsinger, J. Am. Chem. Soc. 124 (2002) 15030.

[126] R.V. Rughani, J.R. Schneider, MRS Bull. 33 (2008) 530.

[127] J.K. Kretsinger, L.A. Haines, B. Ozbas, D.J. Pochan, J.P. Schneider, Biomaterials 26 (2005) 5177.

[128] D.A. Salick, J.K. Kretsinger, D.J. Pochan, J.P. Schneider, J. Am. Chem. Soc. 129 (2007) 14793.

[129] M.C. Branco, D.J. Pochan, N.J. Wagner, J.P. Schneider, Biomaterials 30 (2009) 1339

[130] A. Mishra, J.J. Panda, A. Basu, V.S. Chauhan, Langmuir 24 (2008) 4571.

[131] S. Gudlur, M. Warner, Y. Hiromasa, T. Iwamoto, J.M. Tomich, Biophys. J. 96 (3) (2009) 634a.

[132] Y.-b. Lim, O.-J. Kwon, E. Lee, P.-H. Kim, C.-O. Yun, M. Lee, Org. Biomol. Chem. 6 (2008) 1944.

[133] Y.-b. Lim, E. Lee, Y.R. Yoon, M.S. Lee, M. Lee, Angew. Chem. Int. Ed. 47 (2008) 4601.

[134] Y.-b. Lim, S. Park, E. Lee, J.-H. Ryu, Y.-R. Yoon, T.-H. Kim, M. Lee, Chem. Asian J. 2 (2007) 1363.

[135] Y.-C. Yu, P. Berndt, M. Tirrell, G.B. Fields, J. Am. Chem. Soc. 118 (1996) 12515.

[136] S. Cavalli, E.E. Tellers, M.R.J. Vos, B.P. Pichon, M. Overhand, H. Rapaport, N.A.J.M. Sommerdijk, A. Kros, Angew. Chem. Int. Ed. 45 (2006) 739.

[137] C.L. Jenkins, R.T. Raines, Nat. Prod. Rep. 19 (2002) 49.

[138] L. Vitagliano, R. Berisio, L. Mazzarella, A. Zagari, Biopolymers 58 (2001) 459.

[139] J. Bella, M. Eaton, B. Brodsky, H. Berman, Science 266 (1994) 75.

[140] A.V. Persikov, B. Brodsky, Pept. Sci. 55 (2000) 436.

[141] D.G. Wallace, J. Rosenblatt, Adv. Drug Deliv. Rev. 55 (2003) 1631.

[142] L. Ma, C. Gao, Z. Mao, J. Zhou, J. Shen, X. Hu, et al., Biomaterials 24 (2003) 4833. 
[143] H.A. Awad, M.T. Harris, R.E. Ibrahim, Y. Wu, R.G. Young, S. Kadiyala, G.P. Boivin, J. Biomed. Mater. Res. 51 (2000) 233.

[144] X.B. Yang, R.S. Bhatnagar, S. Li, R.O.C. Oreffo, Tissue Eng. 10 (2004) 1148.

[145] C.H. Lee, A. Singla, Y. Lee, Int. J. Pharm. 221 (2001) 1.

[146] J.E. O’Grady, D.M. Bordon, Adv. Drug Deliv. Rev. 55 (2003) 1699.

[147] R.M. Suri, J.M. Austyn, J. Immunol. Methods 214 (1998) 149.

[148] A.K. Lynn, W. Bonfield, J. Biomed. Mater. Res. Part B 71 (2004) 343.

[149] M. Sakaguchi, H. Hori, S. Hattori, S. Irie, A. Imai, M. Yanagida, et al., J. Allergy Clin. Immunol. 104 (1999) 695.

[150] R. Valluzzi, D.L. Kaplan, Biopolymers 53 (2000) 350.

[151] T. Koide, D.L. Homma, S. Asada, K. Kitagawa, Bioorg. Med. Chem. Lett. 15 (2005) 5230.

[152] S. Rele, Y. Song, R.P. Apkarian, Z. Qu, V.P. Conticello, E.L. Chaikof, J. Am. Chem. Soc. 129 (2007) 14780.

[153] J.L. Lauer-Fields, N.B. Malkar, G. Richet, K. Drauz, G.B. Fields, J. Biol. Chem. 278 (2003) 14321.

[154] C. Fields, D. Mickelson, S. Drake, J. McCarthy, G. Fields, J. Biol. Chem. 268 (1993) 14153.

[155] C.D. Reyes, A.J. Garcia, J. Biomed. Mater. Res. Part A 65 (2003) 511

[156] S.T. Khew, Q.J. Yang, Y.W. Tong, Biomaterials 29 (2008) 3034.

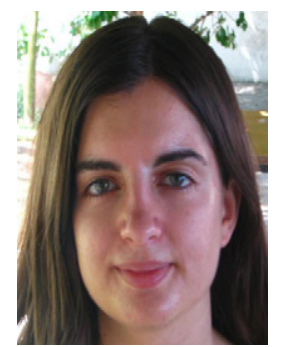

Sila Toksöz graduated from the department of Molecular Biology and Genetics at the Middle East Technical University, Turkey. She is currently a graduate student at UNAM-Institute of Materials Science and Nanotechnology. Her research interests include self-assembling peptide amphiphiles and their uses in regenerative medicine.

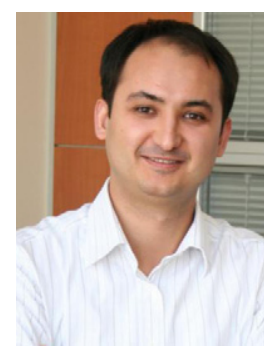

Mustafa 0. Guler is an assistant professor at UNAM-Institute of Materials Science and Nanotechnology, Bilkent University. He received his Ph.D. degree in chemistry from Northwestern University in Evanston, IL, USA in 2006. After receiving his $\mathrm{PhD}$, he had worked at the Institute for Bionanotechnology in Medicine at Northwestern University and Nanotope Inc. in Chicago, IL, USA until 2008. His research is based on discoveries of nanostructures at the interface of chemistry, biology, and materials science. 